\title{
Study of Comparative Performance of Systems of Cultivation of Tomato (Solanum lycopersicum L.) and Coriander (Coriandrum sativum L.) for Growth and Yield Characters
}

\author{
P. Irene Vethamoni \\ Department of Vegetable Crops, Horticultural College and Research Institute, \\ Tamil Nadu Agricultural University, Coimbatore - 641003.
}

\begin{abstract}
The vegetable crops viz., TNAU tomato hybrid $\mathrm{CO} 3$ and coriander variety $\mathrm{CO} 4$ were raised under different cultivation systems viz., 50 per cent shade net, insect proof net house and open field conditions. Growth and yield characters of tomato and coriander were assessed during s ummer 2013 and 2014 under different systems of cultivation. The number of fruits per plant (54.3) and weight of fruits per plant $(2.1 \mathrm{~kg})$ with estimated yield $(67.17 \mathrm{t} / \mathrm{ha})$ of TNAU tomato hybrid CO 3 was highest under insect proof net house followed by shade net house and the lowest was noticed under open field cultivation. The highest single plant weight $(52.1 \mathrm{~g})$ with estimated herbage yield ( $3.33 \mathrm{t} / \mathrm{ha}$ ) of coriander were recorded under insect proof net house followed by shade net and the lowest under open field cultivation. Among the two crops, the highest BCR (2.58) was observed with tomato hybrid $\mathrm{CO} 3$ under insect proof net house followed by shade net house (2.45). The lowest BCR of 1.31 was recorded with the cultivation of coriander variety CO 4 under open field condition. Therefore, it can be concluded that tomato could be highly remunerative crop suitable for cultivation under insect proof net house condition during summer season.
\end{abstract}

Key words: Coriander, Tomato hybrid, 50 \% Shade net, Insect proof net house, Yield

Tomato (Solanum lycoperisum L.) belongs to the family Solanaceae is one of the most important and popular vegetables in the tropics and subtropics of the world because of its wider adaptability, high yielding and suitability of variety of uses in fresh as well as processed food industries (Meena and Bhahadur, 2015). It is one of the most important "Protective foods" because of its special nutritive value. In many countries it is considered as "poor man's orange" because of its attractive appearance and nutritive value. The red pigment in tomato (lycopene) is now being considered as the "world's most powerful natural antioxidant". It is rich source of vitamin A (320 I.U.), vitamin C (31 mg), potassium (114 mg), phosphorous (36 mg), calcium (20 mg), iron $(1.8 \mathrm{mg})$, protein $(1.9 \mathrm{mg})$ and other minerals and fibres (Aykroyd, 1963). Tomatoes are used in the preparation of soup, salad, pickles, ketchup, puree, sauces and also consumed as a vegetable in many other ways.

In India, tomato is cultivated in an area of 0.76 million ha with an annual production of 18.34 million tonnes (NHB database, 2015-2016). In Tamil Nadu, it is grown over an area of 25,3700 ha with $3,28,200$ tonnes of annual production during the year 2014-2015 (NHB database, 2015). Even though tomato is cultivated in larger area, it is affected by high temperature when it is grown under open field condition. Tomato is very sensitive to a number of environmental stress, especially drought, high temperature and salinity (Kalloo and Berg, 1993).

${ }^{*}$ Corresponding author email: irenevetha17@gmail.com
Coriander (Coriandrum sativum L.) is a herb that is extensively used around the world as condiment, as well as for medicinal purpose. Its leaves and fruits have eleven components of essential oils, six types of acids minerals and vitamins, each having a number of medicinal properties. Coriander is a tropical crop, optimum temperature for germination and early vegetative growth of coriander is $20-25^{\circ} \mathrm{C}$. Its yield is highly affected by high temperature during summer. Since tomato and coriander are highly affected by temperature during summer season it is necessary to find out the suitable alternate low cost technology for off season cultivation of these vegetables.

Kavitha (2005) and Smith et al. (1984) reported that tomato plants grown under shade tend to produce higher fruit yields (15\%) than those grown in open. They also reported that yield of tomato is higher under shade during summer season than grown in open field. With this background, the present study was undertaken to find the most efficient system of cultivation for off season production of tropical vegetables viz., tomato and coriander.

\section{Material and Methods}

Two field experiments with TNAU tomato hybrid CO 3 and coriander variety CO 4 were conducted separately at the university orchard, Tamil Nadu Agricultural University, Coimbatore during summer season of 2013 and 2014 under different systems of cultivation. Each experiment was laid out under randomized block design with four replications. 
Tomato and coriander crops were raised under three cultivation systems viz., open field cultivation, shade net cultivation and insect proof net house.

\section{Experiment I}

The tomato hybrid $\mathrm{CO} 3$ was planted in paired row system with row to row spacing of $60 \mathrm{~cm}$ and plant to plant with $60 \mathrm{~cm}$. Cultural practices were followed as per the package of practices recommended for Tamil Nadu (Crop production techniques of horticultural crops, 2013). Five plants from each treatment in each replication were selected at random and utilized for recording observations on the following characters viz, number of fruits per plant, weight of fruits per plant $(\mathrm{kg})$, single fruit weight $(\mathrm{g})$, length and girth of fruit $(\mathrm{cm})$, yield per plant, yield per hectare $\left(\mathrm{t} \mathrm{ha}^{-1}\right)$, number of seeds per fruit, weight of seeds per fruit (g) and 100 seed weight (g) in tomato.

Table 1. Yield and yield attributing characters of TNAU tomato hybrid CO 3 under different systems of cultivation

\begin{tabular}{|c|c|c|c|c|c|}
\hline Characters & Insect proof net house & Shade net house & Control & SEd & CD@ $5 \%$ level \\
\hline No. of fruits plant ${ }^{1}$ & 54.3 & 45.7 & 32.6 & 1.863 & 5.175 \\
\hline Weight of fruits plant ${ }^{1}(\mathrm{~kg})$ & 2.1 & 1.72 & 0.87 & 0.058 & 0.161 \\
\hline Fruit weight (g) & 57.0 & 41.5 & 30.4 & 2.801 & 7.78 \\
\hline Length of fruit (cm) & 4.3 & 3.35 & 2.17 & 0.073 & 0.202 \\
\hline Width of fruit $(\mathrm{cm})$ & 3.8 & 2.51 & 1.78 & 0.126 & 0.35 \\
\hline Girth of fruit $(\mathrm{cm})$ & 15.3 & 12.2 & 8.5 & 0.201 & 0.558 \\
\hline No. of seeds fruit ${ }^{1}$ & 50.8 & 38.2 & 26.3 & 4.28 & 11.876 \\
\hline Weight of seeds fruit ${ }^{1}(\mathrm{~g})$ & 0.24 & 0.17 & 0.11 & 0.009 & 0.026 \\
\hline 100 seed weight $(\mathrm{g})$ & 0.44 & 0.35 & 0.23 & 0.008 & 0.025 \\
\hline Yield per hectare $\left(\mathrm{t} \mathrm{ha}^{-1}\right)$ & 67.17 & 59.6 & 41.6 & 1.97 & 5.46 \\
\hline
\end{tabular}

Length of tomato fruit was highest under insect proof net house system $(4.3 \mathrm{~cm})$ followed by shade net cultivation system $(3.35 \mathrm{~cm})$. The highest fruit width of $3.8 \mathrm{~cm}$ was observed under insect proof net house system and lowest width of $1.78 \mathrm{~cm}$ was observed under open field cultivation. Fruit girth was highest under insect proof net house with the mean value of $(15.3 \mathrm{~cm})$ and lowest width was noticed under open field cultivation $(8.5 \mathrm{~cm})$. Increased fruit characters noticed under net house might be due to conducive micro climate (temperature, relative humidity and light) and their variability experienced by the plants grown under net house. Vasu and Pugalendhi (2015a) stated that brinjal graft COBH 2 produced big sized fruit with more length and diameter under net house than in open field with the quantum of increase of 9.09 for fruit length and 2.77 per cent for fruit diameter.

The highest fruit weight of 57.0 gram was noticed under insect proof net house system and lowest was observed under open field cultivation (30.4 g). The fruits harvested under shade net house had more weight than under open field condition. This is in conformity with the findings of Vasu and Pugalendhi (2015a) who observed increased value of $48.28 \mathrm{~g}$ of mean fruit weight in grafted brinjal under net house than open field. The quantum increase in net house over open field was $2.15 \%$ for fruit weight. The fruit

\section{Experiment II}

The coriander variety $\mathrm{CO} 4$ was sown with row to row spacing of $30 \mathrm{~cm}$ and plant to plant spacing of $15 \mathrm{~cm}$. Observations on plant height $(\mathrm{cm})$, number of branches, single plant weight $(\mathrm{g})$, number of compound leaves, length of root per plant $(\mathrm{cm})$, leaf weight per plant $(\mathrm{g})$, root weight per plant $(\mathrm{g})$ were recorded in ten plants in each treatment from each replication in coriander.

\section{Results and Discussion}

\section{Yield and yield attributing characters of tomato hybrid}

The mean performance of yield and yield attributing characters of TNAU tomato hybrid $\mathrm{CO} 3$ under different systems of cultivation were recorded and given in Table 1. weight is highly influenced by growing conditions and reduction in fruit size under open might be due to the reduction in the supply of assimilates to developing sink caused by exhaustion through excess respiration (Cockshell et al., 1992).

The highest number of tomato fruits per plant was recorded under insect proof net house (54.3) followed by shade net house (45.7) and the lowest number of fruits was noticed under open field cultivation (32.6). Similar results were observed by Vasu and Pugalendhi (2015b) who stated that increase in number of brinjal fruit under net house might be due to extended harvest with more number of pickings by favourable micro climate prevailed inside the net house than in open field cultivation. Net house cultivation resulted more fruits in grafted brinjal (175.28) while in open field the number of fruits per plant reduced to 130.70 .

Weight of tomato fruits per plant was more under insects proof net house $(2.1 \mathrm{~kg})$ followed by shade net house $(1.72 \mathrm{~kg})$. Cheema et al. (2013) observed not increase in mean fruit weight of different tomato hybrids grown under net house than under open field condition. Number of seeds per fruit was more under insect proof net house (50.8) followed by shade net house (38.2) and lowest count was observed under open field cultivation (26.3). The highest weight of 
seeds per fruit was observed under insect proof net house $(0.24 \mathrm{~g})$ followed by shade net house $(0.17 \mathrm{~g})$ and the lowest seed weight per fruit was recorded under open field cultivation $(0.11 \mathrm{~g})$. Hundred seed weight was more under insect proof net house $(0.44 \mathrm{~g})$ followed by shade net house $(0.35 \mathrm{~g})$ and the lowest weight was recorded under open field cultivation $(0.23 \mathrm{~g})$.

Table 2. Growth and yield characters of coriander variety CO 4 under different systems of cultivation

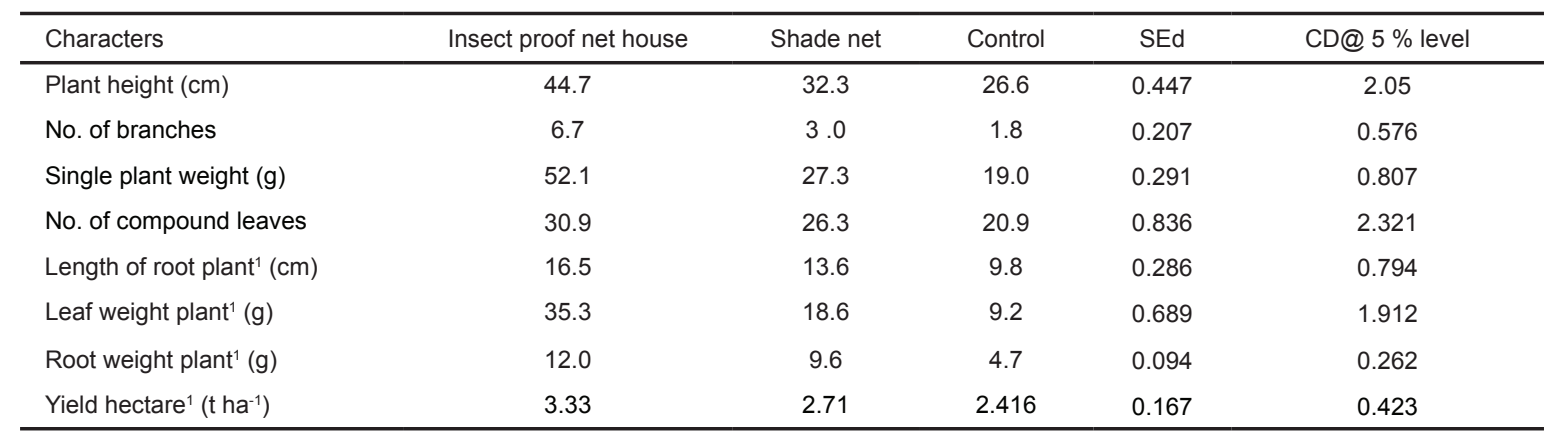

The highest yield of TNAU tomato hybrid $\mathrm{CO} 3$ was recorded under insect proof net house $(67.17$ $\left.\mathrm{t} \mathrm{ha}^{-1}\right)$ followed by shade net house $\left(59.6 \mathrm{t} \mathrm{ha}^{-1}\right)$. Lowest yield was recorded in open field cultivation (41.6 t ha-1). Nangare et al. (2015) obtained similar results that the highest mean tomato fruit yield of (3.49 $\mathrm{kg} /$ plant) was found under net house followed by open field $(2.27 \mathrm{~kg} /$ plant) which might be due to increased formation of photosynthates and their partitioning and distribution for the final sink under net house compared to open. The lowest yield under open condition might be due to reduction in mobilization and translocation of nutrients and photosynthates to the developing parts at high temperature than under shade. These results are in accordance with that of Arunkumar (2000) and Suchindra (2002).

Table 3. Economics of TNAU tomato hybrid CO 3 and coriander variety $\mathrm{CO} 4$ under different systems of cultivation

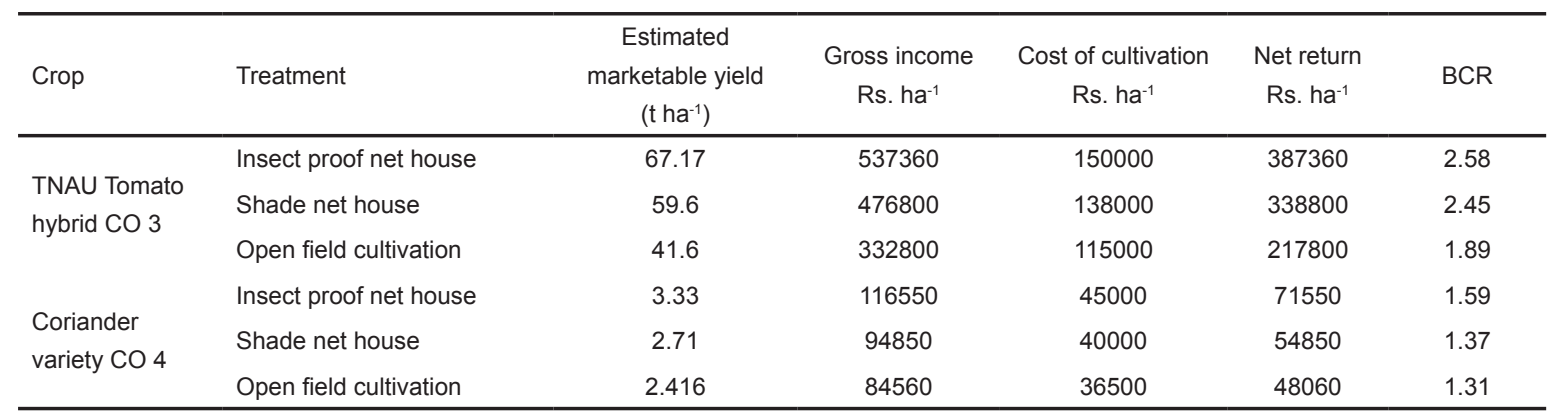

Growth and yield characters of coriander variety

The mean performance of the growth and yield characters of coriander variety $\mathrm{CO} 4$ under different systems of cultivation was recorded and given in Table 2. Plant height of coriander was higher under insect proof net house $(44.7 \mathrm{~cm})$ followed by shade net house $(32.3 \mathrm{~cm})$ and the lowest plant height of $26.6 \mathrm{~cm}$ was recorded under open field cultivation. Cheema et al. (2013) reported that significant increase in plant height in different tomato hybrids grown under net house than open field because of controlled environmental condition. Vasu and Pugalendhi (2015b) reported that plant height of brinjal hybrid was found to be highest under net house at 120 DAT $(111.55 \mathrm{~cm})$ than open field $(76.72)$. In this trial the plants grown under net house were taller compared to open. This might be due to favourable micro climate and their variabilities experienced by the plants grown under net house. More number of branches per plant was recorded under insect proof net house (6.7) followed by shade net house (3.0). Less number of branches was recorded under open field cultivation (1.8). This is in conformity with the findings of Chitra et al. (2016) who reported that the shade net house during off season reduce the temperature up to $5^{\circ} \mathrm{C}$ and increase the relative humidity, thereby providing optimum environmental conditions for the growth of coriander.

The highest single plant weight of $52.1 \mathrm{~g}$ was recorded under insect proof net house followed by shade net cultivation $(27.3 \mathrm{~g})$ and the lowest (19.0 g) was recorded under open field cultivation. Number of compound leaves per plant was more under insect proof net house (30.9) followed by shade net cultivation (26.3). Less number of compound leaves per plant (20.9) was recorded under open field cultivation. Leaf weight per plant was more under insect proof net house with a mean value of $35.3 \mathrm{~g}$ followed by shade net house (18.6 g) and lowest leaf weight was recorded under open field cultivation (9.2 g).Maximum root length of $16.5 \mathrm{~cm}$ was observed under insect proof net house followed by shade net cultivation $(13.6 \mathrm{~cm})$ and the least length was recorded under open filed cultivation $(9.8 \mathrm{~cm})$. Similar kind of result was observed by Vasu and Pugalendhi (2015b) who observed that highest root length of 
$189.70 \mathrm{~cm}$ in grafted brinjal under net house than open field $(154.02 \mathrm{~cm})$. The highest root weight per plant was noticed under insect proof net house (12.0 g) followed by shade net house $(9.6 \mathrm{~g})$ and lowest root weight was noticed under open field cultivation $(4.7 \mathrm{~g})$.

Among the systems of cultivation, coriander yield was high (3.33 $\left.\mathrm{t} \mathrm{ha}^{-1}\right)$ under insect proof net house followed by shade net house $\left(2.71 \mathrm{t} \mathrm{ha}^{-1}\right)$. This is in line with findings of Rajasekar et al. (2013) who observed higher yield of coriander under net house. The yield coriander variety $\mathrm{CO} 4$ was the lowest in open field $\left(2.42 \mathrm{t} \mathrm{ha}^{-1}\right)$. This is in accordance with findings of Chitra et al. (2016) who reported that the unfavourable climatic condition and high temperature prevailing during summer months under open field condition resist the growth and development of coriander.

\section{Economics}

The economics worked out for tomato hybrid $\mathrm{CO}$ 3 under different systems of cultivation proved the highest benefit cost ratio of 2.58 under insect proof net house followed by shade net cultivation (2.45) and less benefit cost ratio of 1.89 was observed under open field cultivation (Table 3 ). Vasu and Pugalendhi (2015a) reported that Ravaiya brinjal graft grown under net house recorded the highest net income of Rs. 830575 / ha with the benefit cost ratio of 3.83 and the Ravaiya brinjal hybrid grown in open field registered the lowest net income of Rs. 135195 /ha with the benefit cost ratio of 1.77 . The highest net income and benefit cost ratio obtained from grafted brinjal hybrid might be due to higher yield and marketable yield per plant under net house followed by open field.

Same trend was observed in coriander cultivation also. The coriander variety CO 4 under insect proof net house recorded the highest cost benefit ratio of 1.59 followed by shade net house cultivation (1.37). The lowest benefit cost ratio of 1.31 was noticed under open field condition. The highest benefit cost ratio (2.58) was observed with tomato hybrid $\mathrm{CO} 3$ under insect proof net house. Therefore it can be concluded that TNAU tomato hybrid $\mathrm{CO} 3$ is a highly remunerative crop for cultivation under insect proof net house during summer season.

\section{Acknowledgement}

The author is highly grateful to the Department of Vegetable crops, Tamil Nadu Agricultural University, Coimbatore, India for providing technical assistance during the research programme.

\section{References}

Arunkumar, R. 2000. Evaluation of certain tomato (Lycopersicon esculentum Mill.) genotypes under greenhouse and open conditioning. M.Sc. thesis, Tamil Nadu Agricultural University, Coimbatore.

Aykroyd, W.R. 1963. Indian Council of Medical Research, Special series. p. 42.
Cheema, D.S., Singh, N. and Jindal, S.K. 2013. Evaluation of indeterminate tomato hybrids for fruit, yield and quality traits under net house and open field conditions. Vegetable Science, 40 (1): 45-49.

Chitra, R., Shoba, N., Sevapriya, P., Lokesh, B., Priyanka and Ramar, A.2016. Off season production of leafy coriander under shade net condition. Indian Journal of Arecanut, spices and medicinal Plants, 18 (2): 37-38.

Cockshell, K.E., Graves, C.J. and Cave, C.R.J. 1992. The influence of shading on yield of glasshouse tomatoes. J. Hort. Sci., 67: 11-24.

Crop production techniques of horticultural crops, 2013. Horticultural College Horticultural College and Research Institute, Tamil Nadu Agricultural University, Coimbatore.

Ganesan, M. 2001. Effect of Poly-Greenhouse on plant microclimate and fruit yield of tomato. JRD Tata Ecotechnology Centre. M.S. Swaminathan Research Foundation.

Kalloo, G. and Berg, B.O. 1993. Genetic improvement of vegetable crops. Pergamon Press Ltd., pp. 645-666.

Kaur, S., Bal, S.S., Singh, G., Sindhu, A.S. and Dhillon, T.S. 2004. Management of brinjal shoot and fruit borer, Leucinodes orbonalis Guenee through net house cultivation. Acta Hort., 659: 345-350.

Kavitha, M. 2005. Studies on the effect of shade and fertigation on growth, yield and quality of tomato (Lycopersicon esculentum Mill.). Ph.D. Thesis, Tamil Nadu Agricultural University, Coimbatore.

Meena, O.P. and Bahadur, V. 2015. Genetic associations analysis for fruit yield and its contributing traits indeterminate tomato (Solanum lycopersicum L.) germplasm under open field condition. J. Agric. Sci., 7: 3 .

Nangare, D.D., Singh, J., Meena, V.S., Bhushan, B. and Bhatnagar, P.R. 2015. Effect of green shade nets on yield and quality of tomato (Lycopersicon esculentum Mill) in semi-arid region of Punjab. Asian J. Adv. Basic Appl. Sci., 1 (1): 1-8.

NHB data base. 2015. Tomato, area, production and productivity.

Parvej. M.R., Khan, M.A.H. and Awal, M.A. 2010. Phenological development and production potentials of tomato under polyhouse climate. The Journal of Agricultural Science, 5 (1): 34-42.

Rajasekar, M., Arumugam, T. and Ramesh Kumar, S. 2013. Influence of weather and growing environment on vegetable growth and yield. J. Hortic. For., 5 (10): 160-167.

Smith, I.E., Savage, M.J. and Mills, P. 1984. Shading effects on green house tomatoes and cucumbers. Acta Hort., 148: $491-500$.

Suchindra, R. 2002. Studies on evaluation of tomato (Lycopersicon esculentum Mill.) hybrids under four different growing environments for yield and quality characters. M.Sc. Thesis, Horticultural College and Research Institute, Periyakulam.

Vasu, N and Pugalendhi, L. 2015a. Evaluation of brinjal grafts and incidence of shoot and fruit borer (Leucinodes orbonalis Guenee) under controlled conditions. Annals of Plant and Soil Research, 17 (Special Issue): 199-204.

Vasu, N and Pugalendhi, L. 2015b. Studies on the performance of grafted brinjal (Solanum melongena L.) under net house and open field conditions. Annals of Plant and Soil Research, 17 (Special Issue): 205-211. 